\title{
Identification and Antibiotic Resistance of Streptococcus agalactiae from Red Hybrid Tilapia (Oreochromis niloticus) in Local Wet Markets
}

\author{
Auzureen MZA ${ }^{1}$, Hamdan $\mathrm{RH}^{1}$, Jamaludin $\mathrm{MH}^{2}$ \\ ${ }^{1}$ Faculty of Veterinary Medicine, University Malaysia Kelantan, Pengkalan Chepa, Kelantan, Malaysia \\ ${ }^{2}$ Faculty of Agro Based Industry, University Malaysia Kelantan, Jeli, Kelantan, Malaysia \\ ainauzureen@gmail.com
}

\begin{abstract}
The existence of ethiology disease like Streptococcus agalactiae could be major problems in aquaculture field. In this study, investigations of red tilapia sold around local wet market were recorded. To detect the $S$. agalactiae in wet markets from disease potential and measure the antibiotic susceptibility test. Selected organs such as eyes, gills, heart and intestine were inoculated onto blood agar and incubated at $37^{\circ} \mathrm{C}$ for $24 \mathrm{~h}$. Morphology of S. agalactiae were Gram-positive, translucent pin point colony, and has oxidase and catalase negative. Eight isolates of $S$. agalactiae were confirmed using PCR. The isolates samples were susceptible to imipenem $(10 \mu \mathrm{g})$, gentamicin $(10 \mu \mathrm{g})$, ciprofloxacin $(5 \mu \mathrm{g})$ and nalidixic acid $(30 \mu \mathrm{g})$. In contrast, they were resistance to ampicillin $(10 \mu \mathrm{g})$, amoxicillin-clavulanic $(20 / 10 \mu \mathrm{g})$, erythromycin $(5 \mu \mathrm{g})$, neomycin $(30 \mu \mathrm{g})$, norflaxacin $(10 \mu \mathrm{g})$, streptomycin $(10 \mu \mathrm{g})$ and trimethoprim-sulphamethoxazole $(1.25 / 23.5 \mu \mathrm{g})$. Furthermore, the occurrence of resistant isolates is a matter of public health concern.
\end{abstract}

Key Words: MAR Index, Local Wet Market, Susceptible Test

\section{INTRODUCTION}

At hot seasons in Malaysia, outbreaks of Streptococcus agalactiae were isolated from red hybrid tilapia cultures were most reported at hot seasons in Malaysia. S. agalactiae is one of the streptococcal species most frequently associated with disease from warmblooded terrestrial and cold-blooded aquatic range (Evans et al. 2002). Bacterial infections among freshwater aquaculture species are currently widespread and it became big problem to fish breeders and farmers. Hence, it is important to prevent rather than cure. Tilapia species tend to infected if the temperature is too high or low. Temperature below $12.2^{\circ} \mathrm{C}$ is when tilapia loses their resistance to disease and subject to infections by bacteria, fungi and parasites (Parker 2011). High water temperature were caused the high prevalence of infections especially in large water bodies like reservoirs and dams (Aisyhah et al. 2015). Nile tilapia is a tropical species and preferred temperature ranging from 31 to $36^{\circ} \mathrm{C}$. There are increasingly numerous of fish disease that appear in freshwater fishes and cause severe economic loses every year from countries around the world (Pourgholam et al. 2013). Najiah et al. (2012) highlighted that the biosafety level of bacterial infection in freshwater fish in Malaysia is still lacking. Our goal of research was to isolates S. agalactiae from red hybrid tilapia and more understanding into antibacterial susceptibility test. Definitely, antibacterial susceptibility test were included in research to know how bacteria detected will react with the multiple types of antibiotics.

\section{MATERIAL AND METHODS}

\section{Samples collection}

Tilapia fish samples weighing between 300 to $400 \mathrm{~g}$ were collected from different area of wet market. The fish samples were collected from October until December 2015. 
Samples were taken from Pulau Melaka, Jelawat, Binjai, Pantai Baru, Kota Bharu, Kubang Tin, Binjai Kecil, Wakaf Zin, Tumpat, Morak, Kubang Kerian and Pasar Siti Khadijah. The fish were transported aseptically consists 36 dead fish from 12 sampling area to laboratory for further.

\section{Isolation and identification of bacteria}

The organ samples, eyes, gills, heart and intestine were aseptically collected from each tilapia fish for bacteria isolation using Columbia blood agar (Oxoid, UK). The organs of tilapia were aseptically dissected and streaked on BA. Then, the cultures incubated at $37^{\circ} \mathrm{C}$ for $24 \mathrm{~h}$. Suspected $S$. agalactiae colonies were selected and further morphology and biochemical test were done such as Gram staining catalase, oxidase, and indole. Then, $S$. agalactiae confirmation was done by using polymerase chain reaction. The bacterial samples were preserved at $-20^{\circ} \mathrm{C}$ in BHI broth containing $20 \%$ glycerol $(\mathrm{v} / \mathrm{v})$.

\section{Bacterial DNA extraction}

The isolates were grown in $\mathrm{BHI}$ broth and inoculated at $37^{\circ} \mathrm{C}$ overnight. DNA kits (Macherey-Nagel, Germany) was used to extract and purify DNA in this study according to manufacturer's protocol.

\section{Conventional polymerase chain reaction}

PCR amplification was performed using a thermocycler (Biorad, US). The reaction mixture was prepared according to protocol (Ali et al. 2010). Briefly, the reaction mixture consists of $2.5 \mu \mathrm{l}$ of master mix, $1.0 \mu \mathrm{L}$ of forward and reverse primer, $2.0 \mu \mathrm{l}$ of DNA template and $8.5 \mu \mathrm{l}$ of deionized distilled water which made $25 \mu \mathrm{l}$ in total volume. Thirty five PCR cycles were run under the following conditions, $94^{\circ} \mathrm{C}$ of initial denaturation for 4 min, denaturation at $94^{\circ} \mathrm{C}$ in $1 \mathrm{~min}$, annealing at $55^{\circ} \mathrm{C}$ for $1 \mathrm{~min}$, both extension and final extension at $72^{\circ} \mathrm{C}$ in $1 \mathrm{~min}$. PCR products were analyzed in $1.5 \%$ agarose gel electrophoresis for $40 \mathrm{~min}$ at $100 \mathrm{~V}$. The gel was visualized and captured by using Geldoc (Biorad, US)

\section{Antimicrobial susceptibility test (AST)}

AST was performed using 12 types of Kirby-Bauer disk diffusion. The bacterial colony was inoculated in physiological saline and compared with 0.5 MacFarland standard. Then, the suspension was inoculated onto Mueller Hinton agar. After that, the antibiotics disc was applied onto the agar. Twelve types of antibiotics discs were used; ampicillin (10 $\mu \mathrm{g})$, amoxicillin-clavulanic $(20 / 10 \mu \mathrm{g})$, erythromycin $(5 \mu \mathrm{g})$, gentamicin $(10 \mu \mathrm{g})$, imipenem $(10$ $\mu \mathrm{g})$, nalidixic acid $(30 \mu \mathrm{g})$, neomycin $(30 \mu \mathrm{g})$, norflaxacin $(10 \mu \mathrm{g})$, streptromycin $(10 \mu \mathrm{g})$, tetracycline $(30 \mu \mathrm{g})$, ciprofloxacin $(5 \mu \mathrm{g})$ and trimethoprim-sulphamethoxazole $(1.25 / 23.5$ $\mu \mathrm{g})$. Zone of inhibition was measured and analysed according to clinical laboratory standards institute.

MAR index formula:

(Total case of antibiotic resistance) $\times$ (Total number of isolates)

(Total number of antibiotics) 
A MAR index value greater than 0.2 is considered indicate from a high-risk antibioticexposed source (Sarter et al. 2007) or also considered having a high risk sources of contamination from human, poultry, swine or dairy cattle where antibiotics often used (Vivekanandhan et al. 2002).

\section{RESULTS AND DISCUSSION}

\section{Isolation and identification of S. agalactiae}

144 isolated were presumptive as Streptococcus sp. All the isolates showed Gram positive, ß-haemolysis on blood agar, catalase negative and oxidase positive. However, only eight isolates were confirmed S. agalactiae using PCR (Pourgholam et al. 2013). Band size $220 \mathrm{bp}$ was produced on the gel.

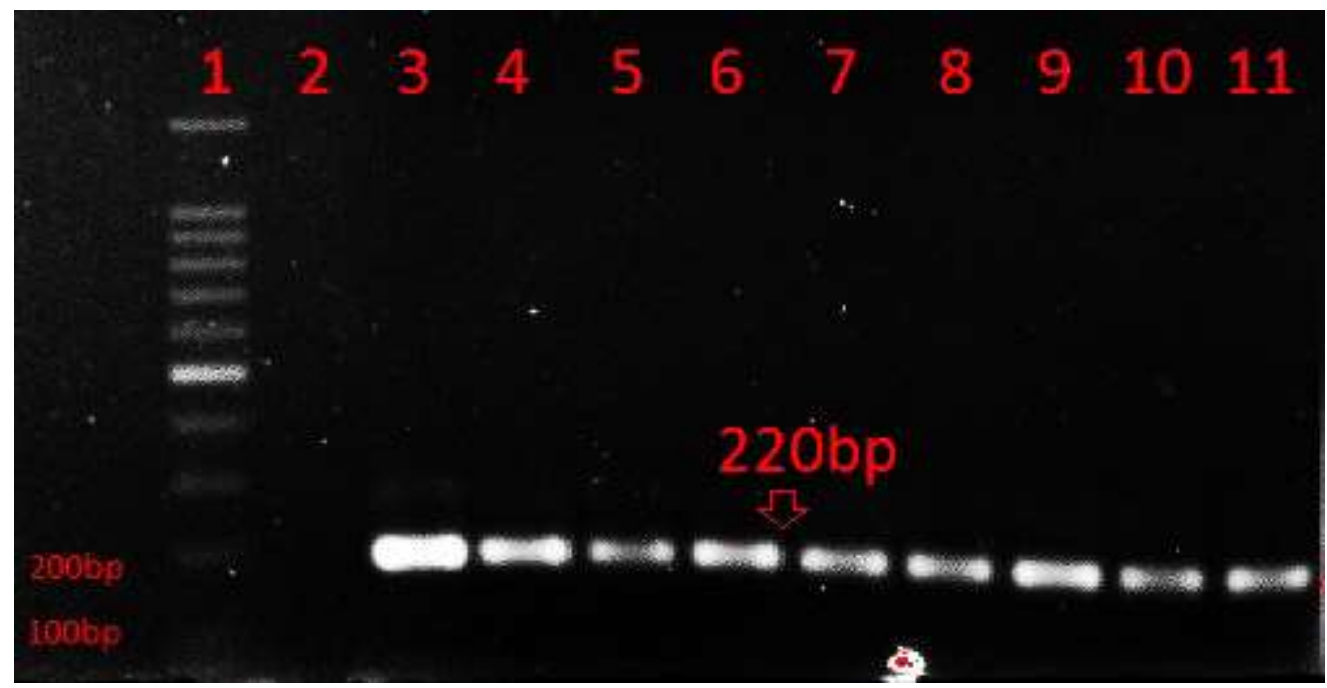

Lane 1: Ladder; Lane 2: Negative control; Lane 3: Positive control; Lane 4: BK2Iy (intestine isolated from Binjai Kecil area 1); Lane 5: BK2Io (intestine isolated from Binjai Kecil area 2); Lane 6: KK3E (eyes isolated from Kubang Kerian); Lane 7: KB1E (eyes isolated from Kota Bharu); Lane 8: B2Go (gills isolated from Binjai Town); Lane 9: PSK2G (gills isolated from Pasar Siti Khadijah); Lane 10: BK3Ho (heart isolated from Binjai Kecil area 2); Lane 11: BK3Hy (heart isolated from Binjai Kecil area 1); Of the 144 Streptococcus isolates, only eight isolates was confirmed to be $S$. agalactiae

Figure 1. Agarose gel showed PCR identification for 8 potential samples of $S$. agalactiae specific primer

\section{Antibacterial susceptibility test}

MAR index revealed imipenem and norflaxacin has lower value than 0.2 and considered from high risk sources of antibiotic exposed sources and rarely used. In this study neomycin, ampicillin and amoxicillin-clavulanic verdict the high resistance responses which are $62.5 \%$. Instead, the other isolates showed the sensitive response to imipenem (75\%), gentamicin (62.5\%) ciprofloxacin and nalidixic acid (50\%). Gentamicin sensitive response was corresponding with farmed red tilapia in Selangor (Ali et al. 2010) and in lake in Malaysia (Aisyhah et al. 2015). Tilapia isolates from local wet market in Penang showed susceptible to ciprofloxacin and trimethoprim-sulphamethoxazole and resistant to tetracycline (Budiati et al. 2013). This result in concordance with CastroEscarpulli et al. (2003) found the nalidixic acid was in susceptible to S. agalactiae isolated 
from frozen freshwater fish in local market. Meanwhile, the same author reported the highest resistance were gentamicin $(58.4 \%)$, erythromycin $(54.5 \%)$ meanwhile.

Differences in resistance and susceptibility measurement to same antibiotics among result could be due to differences antibiotics given since in fish pond. This also might be because of the different fish culture environment or disease history. Streptococcus spp. is considered a diverse group of bacteria that possess the capacity to infect a wide range of hosts (Amal \& Zamri-Saad 2011).

Table 1. Resistance rate of each positive $S$. agalactiae with MAR index

\begin{tabular}{lcc}
\hline \hline Name & Organ & Resistance \\
\hline BK2Iy & Intestine & AMP, AMC \\
BK2Io & Intestine & AMP, AMC, CIP \\
KK3E & Eyes & AMP, AMC, N, CN, S \\
KB1E & Eyes & AMP, AMC, N, CN, E, S \\
B2Go & Gills & AMP, AMC, N, E, CIP, IPM, SXT, NA, NOR, TE, E \\
PSK2G & Gills & CIP, SXT, N, NOR, NA, TE, CN, S \\
BK3Ho & Heart & SXT, N, E \\
BK3Hy & Heart & NA \\
\hline
\end{tabular}

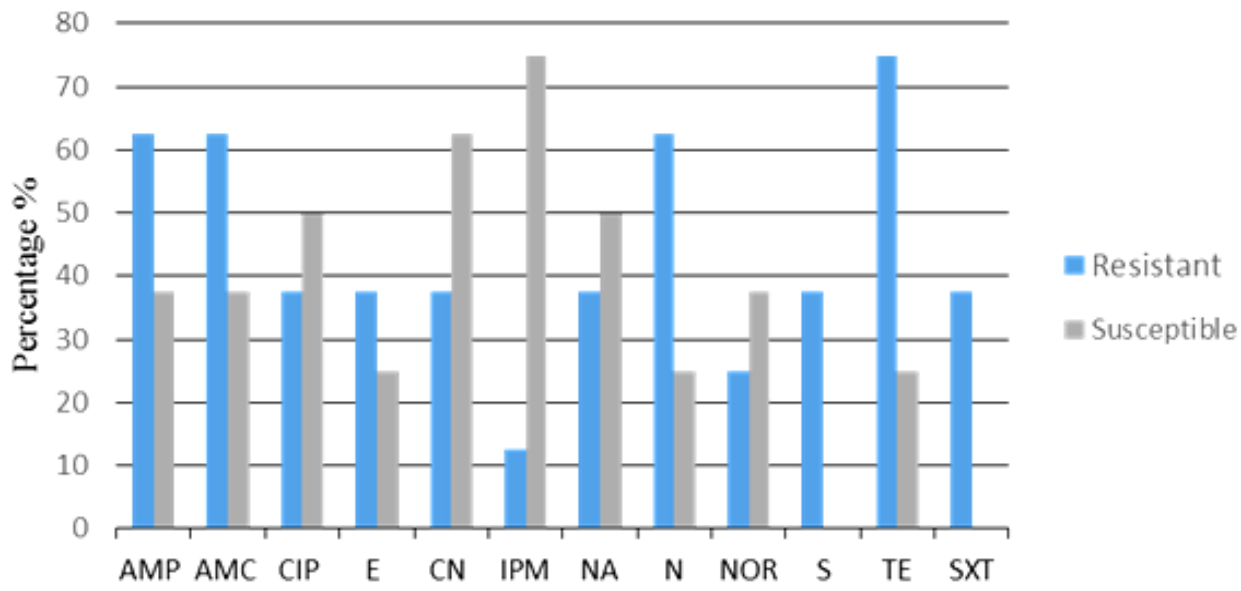

AMP: Ampicillin; AMC: Amoxicillin-clavulanic; CIP: Ciprofloxacin; E: Erythromycin; CN: Gentamicin; IPM: Imipenem; NA: Nalidixic acid; N: Neomycin; NOR: Norflaxacin; S: Streptomycin; TE: Tetracycline; SXT: Trimethoprim-sulphamethoxazole

Figure 2. Antibiotic susceptibility of $S$. agalactiae

In Malaysia, outbreaks of $S$. agalactiae were mostly reported in cultured red hybrid tilapia, O. niloticus $\times$ O. mossambicus (Peters), during hot seasons (Aisyhah et al. 2015). Evans et al. (2002) mention Streptococcus could be transmitted between fish farm and wild animal in same aquatic environment.

Table 1 indicated the division of organ type and location where intestine isolates from Binjai Kecil area 1 and 2, eyes isolates from Kubang Kerian and Kota Bharu, gills isolates from Binjai town and Pasar Siti Khadijah and heart isolates were from Binjai Kecil area one and two. Amal et al. (2008) dissected eyes for bacterial isolation, S. agalactiae found in watery brain and haemorrhagic eye samples. The highlight here was not about where tilapia from and which organs more tends could infected aquatic infection but, how local fish farmers handling and managing fish livestock properly. Besides, fishmonger should be 
cautious during fish transportation, clean fish place and applied self-preservation by wear glove and rubber boots. The preventive measures focus on combined aspects of selecting farm location, applying good aquaculture farm practices, utilization of antibiotics and proper vaccination programme (Zamri-Saad 2014).

\section{CONCLUSION}

In conclusion, the antibiogram data showed that $S$. agalactiae isolated were resistant to more than one antibiotics. Furthermore, the presence of $S$. agalactiae in fish is of public health concern. Hence, surveillance programs are needed to monitor on the pathogen dispersion in different sources.

\section{ACKNOWLEDGEMENT}

This research was supported by Niche Research Grant Scheme (NRGS) from Kementerian Pendidikan Malaysia (KPM) for research items.

\section{REFERENCES}

Aisyhah M, Amal M, Zamri-Saad M, Siti-Zahrah A, Shaqinah N. 2015. Streptococcus agalactiae isolates from cultured fishes in Malaysia manifesting low resistance pattern towards selected antibiotics. J Fish Dis. 38:1093-1098.

Ali A, Hassan D, Saleha AA, Siti-Khairani B, Milud A. 2010. Streptococcus agalactiae the etiological agent of mass mortality in farmed red tilapia (Oreochromis sp). J Anim Vet Adv. 9:2640-2646.

Amal MNA, Zamri-Saad M. 2011. Streptococcosis in tilapia (Oreochromis niloticus): A review. Pertanika J Trop Agric Sci. 34:195-206.

Amal MNA, Kutty BM, Abdullah SZ. 2008. Streptococcosis in red hybrid tilapia (Oreochromis niloticus) commercial farms in Malaysia. Aquac Res. 40:630-632.

Budiati T, Rusul G, Wan-Abdullah WN, Arip YM, Ahmad R, Thong KL. 2013. Prevalence, antibiotic resistance and plasmid profiling of Salmonella in catfish (Clarias gariepinus) and tilapia (Tilapia mossambica) obtained from wet markets and ponds in Malaysia. Aquaculture. 372:127-132.

Castro-Escarpulli G, Figueras M, Aguilera-Arreola G, Soler L, Fernandez-Rendoz E, Aparicio GO, Guarro J, Chacon MR. 2003. Characterisation of Aeromonas spp. isolated from frozen fish intended for human consumption in Mexico. Int J Food Microbiol. 84:41-49.

Evans JJ, Kleusius PH, Gilbert PM, Shoemaker CA, Al-Sarawi MA, Landsberg J, Duremdez R. Al-Marzouki A, Al-Zenki S. 2002. Characterization of $\beta$-haemolytic group B Streptococcus agalactiae in cultured seabream, Sparus auratus L and wild mullet, Liza klunzingeri (day), in Kuwait. J Fish Dis. 25:505-513.

Najiah M, Aqilah N, Lee K, Khairulbariyyah Z, Mithun S, Chowdhury AJK, Shaharom-Harrison F, Nadirah M. 2012. Massive mortality associated with Streptococcus agalactiae infection in cage-cultured red hybrid tilapia Oreochromis niloticus in Como River, Kenyir Lake, Malaysia. J Biol Sci. 12:438-442.

Parker R. 2011. Aquacultue science: Cengage Learning.

Sarter S, Nguyen HNK, Hung LT, Lazard J, Montet D. 2007. Antibiotic resistance in Gramnegative bacteria isolated from farmed catfish. Food Control. 18:1391-1396. 
Vivekanandhan G, Savithamani K, Hatha A, Lakshmanaperumalsamy P. 2002. Antibiotic resistance of Aeromonas hydrophila isolated from marketed fish and prawn of South India. Int J Food Microbiol. 76:165-168.

Zamri-Saad M, Amal M, Siti-Zahrah A, Zulkafli A. 2014. Control and prevention of streptococcosis in cultured tilapia in Malaysia: A review. Pertanika J Trop Agric Sci. 37:389340.

\section{DISCUSSION}

\section{Questions}

1. How do you compare Streptococcus agalactia from mammalian and from Tilapia?

2. How is Tilapia in term of antibiotic resistant?

\section{Answers}

1. Using control with sample from people (from hospital).

2. Tilapia is the most resistant to tetracycline, so it will no effect if tetracycline used to treat. 